Volume 12, Number $1(1990 / 1991)$

Sẹtember 1991

JOURNAL OF AFRICAN LANGUAGES AND LINGUISTICS"

Edited by

Gerrit J. Dimmendaal

\title{
CONTENTS
}

WILLIAM J. SAMARIN, The origins of Kituba and Lingala $\ldots \ldots \ldots \ldots \ldots \ldots \ldots \ldots$ 


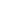


This paper is dedicated to the memory of $F_{r}$. Gustaaf Hulstaert, doyen of the linguistics of central equatorial Africa, who died at Bamanya, Zaire, on 12 February 1990 , after having given his whole life not only to the people of Zaire, but also to the study of its history and languages. After his demise there was sent to me a copy of his work (1989) that is complementary to (and can in some places almost be inter-calated with) the present one. Independently, we came to believe that (1) there was no need for a lingua franca in the equatorial region of the Zaire River in the nineteenth century, (2) foreiga black workers were the first persons to contribute to the creation of Lingala, and (3) the basis of the new language was most importantly Lobangi.

\section{The Origins of Kituba and Lingala}

\section{WILLIAM J. SAMARIN}

Considered here is the relationship between the nature of more-or-less pidginized Kituba and Lingala and their function as lingua francas in equatorial central Africa. It is argued that although they may have been preceded by widely known ethnic languages, it seems more probable that their pidginization and creation as lingua francas took place in the last two tecades of the nineteenth century.

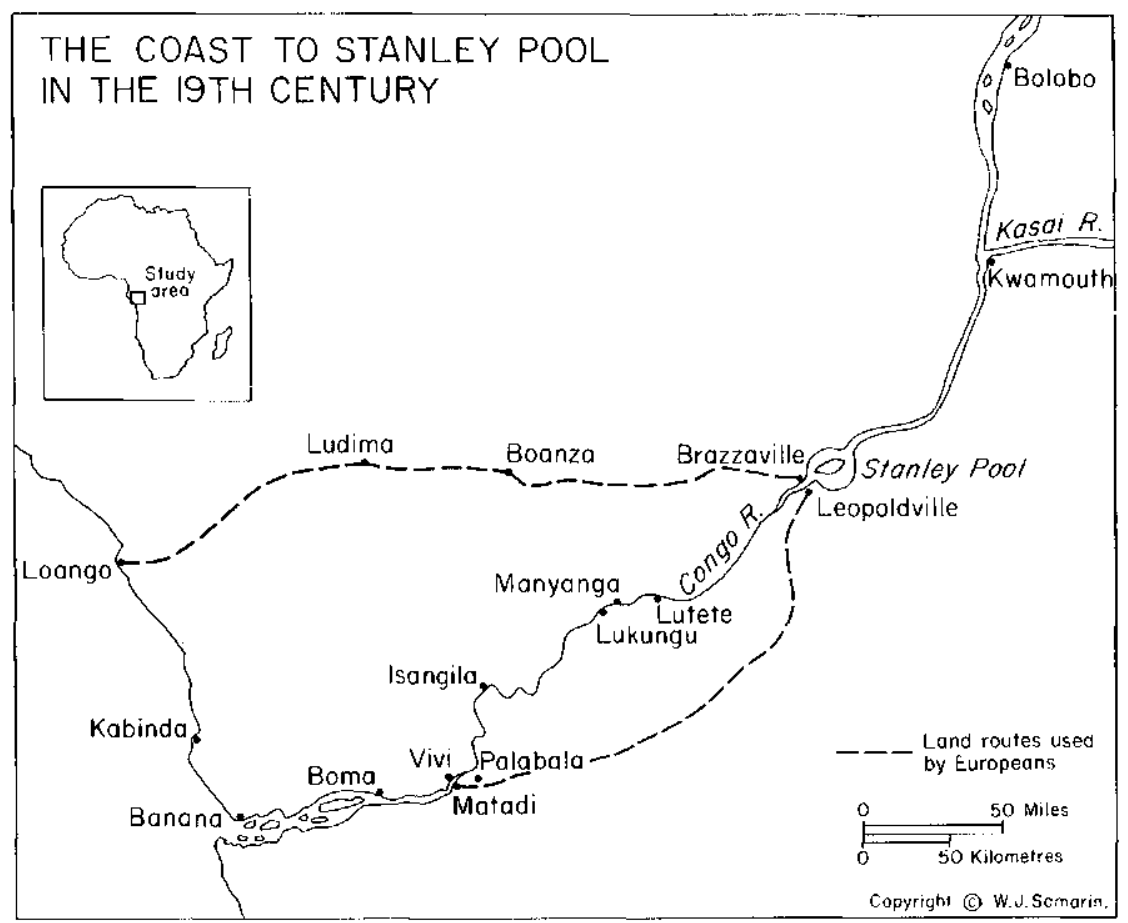

JALL Vol. 12 (1990/1991) 47-77, 0167-6164/90/91 12-47/\$02.75

Copyright $\odot$ by Walter de Gruyter, Berlin 

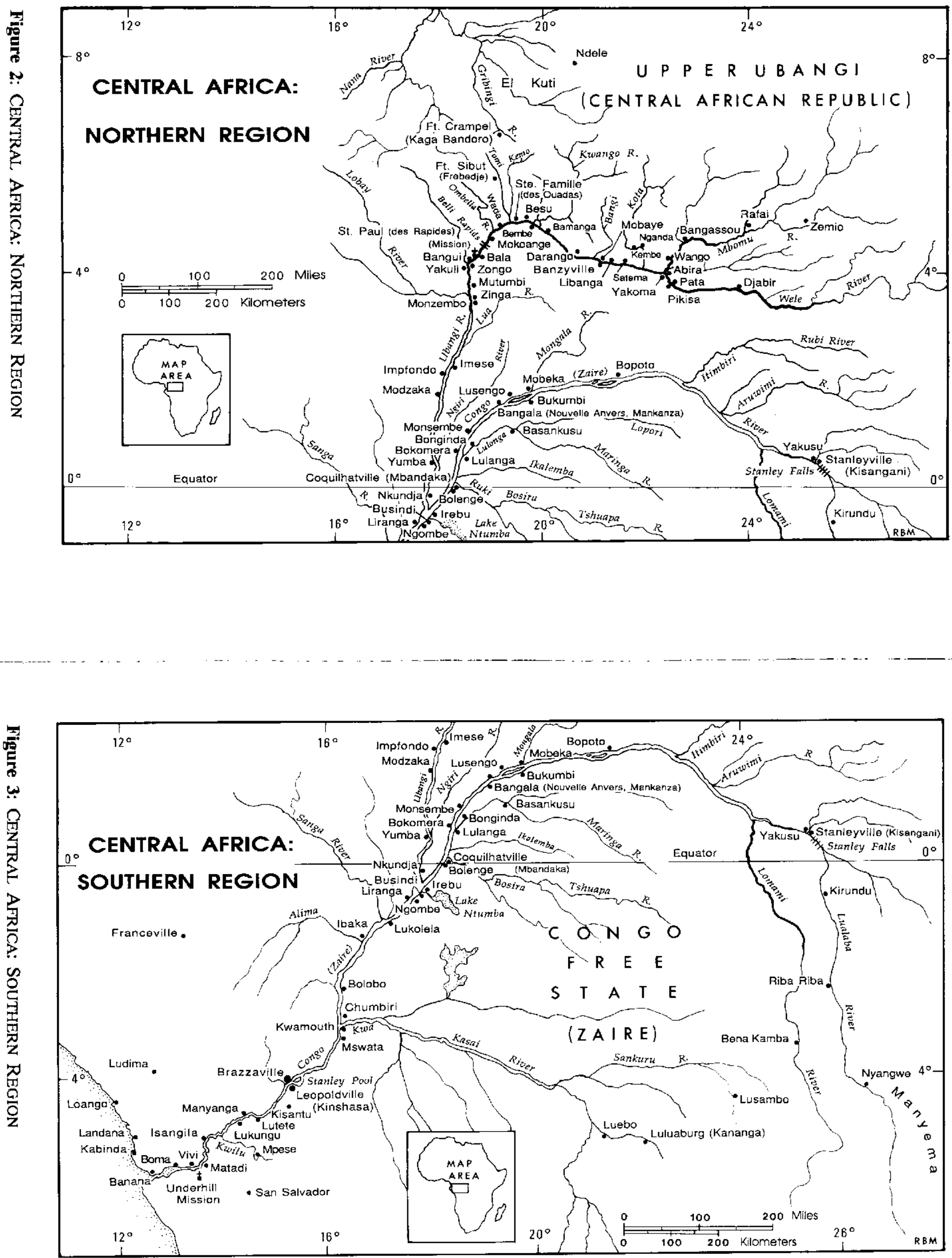


\section{INTRODUCTION*}

There are three major African lingua francas in central Africa, two of them Bantu and one Ubangian: Kituba (also known as Kikongo ya Leta, vehicular Kikongo, etc.), Lingala, and Sango. ${ }^{1}$ They are, however, more than lingua francas in the Congo, Zaire, and the Central African Republic, because they figure to some degree or other as nativized or, as one might say, vernacularized forms of communication, having become,

* Research over a period of seventeen years that led to the writing of this paper was financially assisted by a number of agencies and institutions. At the University of Toronto aid came from the Social Sciences and Humanities Research Committee and the International Studies Program. The Social Sciences and Humanities Research Council of Canada made possible a faculty research leave (1979-1980); it also contributed funds to research costs and made possible two trips to France. Help came as well from the Social Science Research Council (New York) and the Centre National de la Recherche Scientifique of France (CNRS), the latter for 1984 and 1988. Without their help this work would not have been possible. Archives and private libraries were used in a number of places, where the personnel were most helpful in facilitating my work: the Academie des Sciences d'OutreMer, Paris; the Baptist Missionary Society, London, England; Archives Nationales, Section Outre-Mer, Paris, Aix-en-Provence (now the latter); Congrégation du Saint-Esprit, ChevillyLarue (formerly Paris). Earlier versions of this paper were read by Fr. Frans Bontinck, specialist on the history of Zaire, and Harold W. Fehderau; and an abbreviated version was presented in a session on African pidgins and creoles organized by Salikoko Mufwene at the 20th Annual Conference of African Linguistics, Champaign-Urbana, Illinois, April 1989, whose discussant was Mufwene. Their comments are gratefully acknowledged, but the responsibility for this paper lies entirely with me.

1. Swahili is another one, but because its history has not been personally researched it is excluded from the present discussion. Recent works on its role in Zaire's province of Shaba are those of Fabian $(1984,1986)$. There is, of course, much more to be done. It is my conviction that Swahili has left its print on languages of central Africa because of the Zanzibari soldier-workers of the Congo Free State in the nineteenth century. By way of illustration, one can cite, in addition to the many Swahili loans in Lingala (209 according to Knappert 1979), the root in likenzi (plural makenai) for 'roches lateriques', from which iron ore is extracted, in the Libinza language (Mumbanza mwa Bawele 1980(1):236). A borrowing directly from Arabic is not as likely, given the location of the language: along the Ngiri River between the Ubangi and Zaire rivers, no place where Arabic-speaking traders or slave raiders came before the period of colonization. So quickly were Swahili words established that whites thought they were indigenous. In 1892, for example, V. Largeau, providing what he thought was evidence for Arab influence at the mouth of the Bangui River, four or five hours by canoe downriver from Mobaye (and having nothing to do with the military post further west), wrote that "des mots arabs se sont introduits dans leur langue" (referring to Sango, Bubu, and Nzakara living in the area). The only example he gives is cen̈ndouq (for which he provides the Arabic form as well), which, he says, they pronounce sènndoukou for 'caisse' and 'malle'. (Letter to Administrateur principal, Bangui, 18 July 1892, Archives Nationale d'Outre-Mer, Aix-en-Provence, 4(3)D2). Boxes and trunks were, of course, introduced by the colonizing forces, and the word by the Zanzibari. Sanduku is the form the word has in Sango. (It is beyond the scope of this paper to argue against Largeau's, in my opinion, erroneous supposition.) For the possibility of bilingualism in Swahili on the Congo (Zaire) River see below. 
according to one usage of the term, creoles. (On the possibility of considering, at least for Lingala, an origin in creolization without pidginization, see below.)

It was appropriate that these languages be included in $A$ Bibliography of pidgin and creole tanguages, compiled by John E. Reinecke, et al. (1975), for they manifest some of the criteria by which pidgins are known. They have, notwithstanding, been all but ignored when generalizations have been made about pidgins. There has been an unfortunate bias toward pidgins based on European languages, which, it is claimed, arose in the context of the plantation economy (e.g. Romaine 1988:75). More work is needed on African-based pidgins to redress this bias. ${ }^{2}$

One of the tasks to which we must address ourselves is explaining when and in what context these African pidgins arose. This is a historical task to be carried out in a historical manner. A certain amount has been written about Sango (Diki-Kidiri 1981; Samarin 1982a, 1982b, 1984/1985, 1985b). The following remarks are concerned with Kituba and Lingala, whose origins have been dealt with only in a more or less casual manner by others (for which see below).

With respect to their origins, the following possibilities must be considered: That they arose out of widely known languages that were not, however, true lingua francas; that they arose out of lingua francas in the technical sense; that they arose out of somewhat pidginized lingua francas; and that they were created as pidginized lingua francas at the time of colonization. The present study adopts the last alternative and contributes to the argument that these languages arose late in the nineteenth century as a result of the colonization of central Africa. ${ }^{3}$ If the argument falls short of having been "proven", it has the merit of being one that might be falsified or confirmed with further research on the histories of languages of central Africa.

2. This view is shared by Mufwene (1986:133). The only Bantu-based pidgins cited by Thomason and Kaufman (1988) are Kituba and Fanagalo. Sango might have been included among pidgins based on languages other than European ones. This last language, it should be noted, is called "Restructured Sango" by Holm (1988:256) without precedent and without explanation. The concept of restructuring figures frequently in Holm's work (33, $39,41,42,54,69,72)$, but it is never presented as an explicit technical term, and it appears in the Index only with the instnuction "see creolization; pidginization". As a linguistic characterization Sango no more deserves to be called restructured than Kituba does, yet the latter is not called "Restructured Kikongo". Restructuralization is a term used by DeCamp (1971), as cited by Holm (1988:51), without specific reference to his own restructuring.

3. Given the fact that I have also argued for a post-contact origin of Chinook Jargon (1986a), it might be assumed that I have an inclination a priori to believe that all pidgins arose during the modern period of exploration and colonization. This is not the case. I will accept any well argued study of indigenous pidginization. What I cannot accept as true is a simple assertion, even if it is a reasonable one. The histories of pidgins, as with all histories, have to be argued. 


\section{CENTRAL AFRICAN BILINGUALISM}

There do not appear to have been lingua francas in central Africa when whites began to make contact with the indigenous population. ${ }^{4}$ (The contrary view has been suggested by others, as is seen below, with no serious argumentation.) Whites did not find languages used between people whose languages were mutually unintelligible. (The wording of this statement should be recalled when the case of Lingala is taken up, where there seems to be a stronger possibility of its having been preceded by a widely known language.) What Europeans found were many individuals who had acquired the knowledge of other languages, and these were used as guides and interpreters. There were no trade languages in the proper sense of the term, even though all these people engaged in trade and some of them, like the Bakongo, the Bateke, the Bobangi, and the Yakoma, specialized in trade. Of course, it is to be expected that because of their commercial activities, their languages would have been acquired by individuals in other ethnic groups. It is known, for example, that the Bobangi sealed trading relations with others by marriage alliances (Harms 1987:162). They also used to leave some of their own people, a kin or a slave, as surety when goods, like ivory, were taken to be sold elsewhere. These people had to stay in the village of the creditor for several months, if not longer. They would certainly have learned something of the local language. Such people would have become valuable in trade transactions. Even without such alliances there would have been opportunity for buyers and sellers to acquire the languages of other people, for some transactions took several months to complete, during which time the guests lived in the village (Coquilhat 1888:240).

These bilinguals would have been able to acquire fairly good competence, if not native-like fluency, in these other languages. And if the languages of the Bakongo and Bobangi were learned in a similar way by others, we have to assume that they too were well learned. That is to say, there is no reason to believe that these languages (i.e. varieties of Kikongo and Lobangi) would have been simplified in the way that characterizes Kituba and Bangala, as the latter lingua franca was called

4. I would prefer that the term lingua franca be used for cases of bilingualism where members of at least two different speech communities use with each other the language of another speech community. Widespread bilingualism alone in a particular language does not mean that that language is a lingua franca. See Samarin (1987). Trade language is commonly used as a synonym, in some contexts, for lingua franca. 
in the nineteenth century, the name persisting in this century for the more pidginized variety of northeastern Zaire.

\section{KITUBA}

The English expedition to explore the Congo River in 1816 was charged to determine "whether there may not be a correct language of communication between nations," in other words, a lingua franca (Tuckey 1818:386). Nothing of the kind was found. Captain Tuckey did the usual thing in relying on bilinguals as guides and interpreters. (His expeditions, it has to be admitted, did not get very far inland.)

In spite of such evidence Fehderau, from whom we learn a great deal about Kituba, asserts the following: "[Kituba] was the means of communication between the local Kikongo-speaking tribal people and Upper Congo, Lingala or Bangala-speaking strangers. Very early contact is thought to have been made between these peoples through the slavetrade traffic in which they took part" (1962:xi; see also Fehderau 1966, Ngalasso 1982, and Nida and Fehderau 1970:147, 148). Nowhere does Fehderau demonstrate the trade activities of ail Kikongo-speaking peoples and how this trade might have led to some variety of Kikongo becoming a lingua franca. ${ }^{6}$ By way of criticism it might be pointed out that it was

5. However, it is reported that Bakongo men adapted their speech to that of their listeners. This observation was made by Bentley, about his visit to Lovo, approximately twenty-five miles from the mission station called Wathen: "I was trying to speak as nearly as possible the Wathen style, but was frequently corrected, until I found out the change. The women are the heart of the people, and their language is the language of a country. The men travel much, and adapt themselves to listeners" (Missionary Herald 1889:361). This is speech accommodation to a different dialect, probably greatest in pronunciation and vocabulary; it is far from what happened in the creation of the new language. Another case of linguistic accommodation is that of the Nunu who adopted a "Bobangi accent" when they tried to infiltrate the Bobangi trading network (Harms 1987:162).

6. Houis (1971:142) gives even less information. All he says is the following: "Cette langue est née du besoin coercitif de communiquer qui apparut parmi des gens livrés à la traite et au commerce, le long d'axes d'échanges convergeant sur l'embouchure du Congo et la cóte avoisinante." However, Ayibite seems to favor a contact-induced origin (1983:1314): "La situation du kituba dans le Bas-Zaïre tient probablement au fait que les populations dont les différents dialectes sont mutuellement intelligibles n'ont pas éprouve le besoin de recourir à une langue véhiculaire pour se communiquer. Le kituba, "fabrique" pour le négoce cantonne dans sa fonction de langue de "traite". Et quand le colonialisme 's'empare' de cette langue pour entrer en contact avec les populations indigènes et l'impose comme langue de l'administration et de l'enseignement, le kituba se voit conférer des fonctions marginales ..." (I am grateful to Fr. Frans Bontinck for a copy of this paper.) Fehderau himself was less categorical in a work that appeared after the one already cited, in which he makes this statement: "Thus we suggest that the language used by tribes in these contact situations was a pidginized Kikongo" (1966:99, emphasis added). Commenting 
the Teke (also known as Tio) at Stanley (Malebo) Pool who were in contact with Bobangi traders further up the Congo (Zaire) River (Vansina 1973). As a matter of fact, the Teke had settlements as far as Kwamouth, if not even somewhat beyond this place, and were the neighbors there of the Bobangi (Bailey 1894:180; this work covers the period 1884-1888). The Bakongo would not have had very much contact at the Pool with Bobangi, and contact between speakers of varieties of Kikongo and speakers of Bangala (later to be called Lingala) took place, I believe, only after the latter language came into being. ${ }^{7}$ That Kikongo did not have a high profile at the Pool is revealed in statements by George Grenfell. In 1886 he wrote that "At present there is no native of the Pool district who knows enough of English or even of Kixi-Kongo to act as our interpreter up river, so that our means of communication are of the slightest" (Missionary Herald 1886:507). Elsewhere he wrote: "the Kishi-Congo language does not range so far as this place (the Pool)" (Grenfell archives, Baptist Missionary Society, 31 August 1886, p. 608). ${ }^{8}$ Finally, Fehderau's statement linking Kituba with Lingala (or Bangala) in the precolonial period must be considered with reservation, because it simply assumes that this other lingua franca was used at the Pool. Even if a riverine language was shared by Upper or Middle Congo

on an earlier version of the present paper (personal communication, 22 November 1989), he says the following: "I tend to agree with you that it would be more accurate to talk in terms of "speech accommodations" [see fn 5] of Bakongo-speaking groups as they communicated with each other in those trading situations, rather than assume that a pidginized form of what became Kituba arose during those years. However, those speech accommodations could very easily have provided a ready base for further use and development of the language when foreign workers came into the area."

7. However, I do not want to claim that Bangala's "creation" preceded that of Kituba. It is more likely that the two arose about the same time. The linguistic relationship between these two languages is something that needs to be determined. Although it is a topic that cannot be undertaken in this paper, it is worth citing the following. The compiler of a small work on Bangala said, "je me suis toujours fait comprendre depuis Matadi jusqu'au Stanley Falls ..." (Compagnie n.d.:2). There would have been workers and militiamen from the Middle and Upper Congo in Matadi familiar with this language. Is it possible that he spoke with them without realizing that they were not local people? This is possible, but it strikes me as unlikely. One is therefore left with the possibility that local people had also learned to communicate in this language. (This work, obviously prepared for Europeans engaged in trade, is not dated, but Fr. Ghislain de Banville, who generously provided me with a photocopy of it, has reason to believe that it appeared between 1895 and 1897.)

8. Grenfell's statement that W.H. Bentley went to Wathen mission to translate into Kishi-Congo instead of at the Pool because the language there (that is, at the Pool) was "quite divergent" (Grenfell archives, London, 30 December 1887, p. 176) should not necessarily be taken as a reference to the Kikongo variety in place. Grenfell must surely have been referring to the Teke language. All evidence, 100 much to summarize here, points to the fact that Kiteke was the principal language of the Pool (e.g. Medley 1892:169). 
people, it does not follow that it was used at the Pool. Sociolinguistic conditions at the equator were entirely different.

The earliest reference to the ancestor of Kituba is from 1905, when a traveller remarks on "bastard Kikongo", a "hybrid speech" (Torday 1905:135). ${ }^{9}$ Bentley is quoted by his wife as referring to "State Congo" or "Dog-Congo" as being of "no earthly use for spiritual work" (Bentley 1907:285). It may have been of this language that another wrote when he said that "It is not difficult to acquire a few hundred words" (Vincent $1895: 410$ ). It is true that from as early as 1887 we find "broken Congo" being used by the missionary W.H. Bentley in talking with the Bambunu chief Makoko at Lemba (Missionary Herald 1887:356, 359). I take it that the missionary on this occasion was using simple utterances in Kikongo. He probably assumed that the chief would have picked up some Kikongo, having made a trip to San Salvador "a long time ago" and because of the presence of Bakongo traders in the town; "simple matters (in Kikongo) are fairly understood." Because Bentley had a very high regard for Kikongo, recognizing it (Missionary Herald 1888:196) as having "an elaborate and regular grammatical system" of great "subtlety and exactness of idea," it is not likely that he would have deliberately used a pidginized form of the language, in spite of his codeswitching strategy. ${ }^{10}$ On this occasion, however, he was adapting his speech to that of the chief, because, as he reports, he "interspersed" his speech with Kiteke. (The chief's language must have been Kiteke, for when Bentley failed to communicate in Kikongo, simplified as it was, he resorted to a Muteke interpreter who spoke "good Congo". In other words, he communicated with the interpreter in Kikongo, who translated into Kiteke.)

It would therefore appear that there is still no evidence of a pidginized form of Kikongo before the $1890 \mathrm{~s}$.

Linguistic evidence for the work-formation of Kituba comes from the comparison of this lingua franca with all the major Kikongo languages. (The topic of linguistic evidence is taken up again in a following section.) It turns out that it is most closely related to the central languages (Fehderau 1966:76), especially that of Manyanga, precisely the area where so many porters were recruited. The enormity of Bakongo involvement in porterage is seen in the fact that from 90,000 to 100,000 persons (the term men would be too restrictive for accuracy) were used

9. Torday's observation that this form of speech was used in the Kwilu region by the Bayanzi, Bahuana (Bahoni), and Bambala "amongst themselves" and that it "has grown up from the intercourse between tribe and tribe" cannot be taken as evidence for the way the language arose. His remarks are those of a superficial observer. That is to say, he was no privileged observer of the origins of this "hybrid speech".

10. The quotation is that of Robert Cust. 
per year in the 1890 s in the Congo Free State alone; and for a twelveyear period the total number of man-loads going to the coast from Stanley Pool has been estimated at 2,730,533 (Samarin 1985:274, 275). ${ }^{11}$ In other words, although the southern caravan route was especially important in the era before French and Belgian colonization, that was not where the language seems to have developed. And although the Vili, near the coast, were very much involved in the coastal trade earlier than the period here discussed, their language had little effect on vehicular Kongo.

The best explanation to date for the origin of Kituba is that it emerged in the contact between the Bakongo people and the foreign workers, first from the east and west coasts, and then from the Upper Congo. The nature of this contact was intense.

Since I suggest that it was the foreign Africans who pidginized the indigenous language of central Africa, and in the present case Kikongo, we should consider a linguistic explanation proposed by Mufwene. In arguing the limitations of the substrate hypothesis, he implies that it was the indigenous, that is, Bantu-speaking, people of central Africa who were responsible for the origin of Kituba. He says this (1986:136-137): "Thus, it is necessary for the substrate hypothesis to explain why Bantu speakers have to some extent preferred Kwa-like (i.e. isolating) features to their native agglutinative (and concordial) patterns." He apparently does not entertain the idea that foreigners with an isolating language (of which there may have been several) may have been responsible for the change. It can easily be demonstrated that many such persons were in the work force of the Congo Free State and the French agents, for workers-and soldier-workers-were recruited along the west coast of Africa. One can cite those who were called Kru, Hausa, and Senegalese (for which see Samarin 1989a). To get an idea of the linguistic backgrounds of those who were travelling over the caravan routes in Bakongo territory one can consider the group that left Matadi for Stanley Pool in July of 1887 (Dupont 1889:19). It consisted of the following: 11 Kaffir porters in the service of the Congo Free State (presumably native speakers of Zulu or Xhosa), 8 so-called Hausa from the Guinea Coast (one of whom spoke a bit of English), 3 Liberians (who we must take as persons indigenous to Africa, not "American" settlers), and one

11. With the kind of information available there is no justification for stating that "population displacements are doubtful for Kituba (with respect to its origins)..." (Thomason and Kaufman 1988:196). Since they adopt an indigenous origin of the language, it is curious that they should make this apparently contradictory statement (page 196): "Even if Europeans found indigenous pidgins in place when they did arrive, such languages are likely to have disappeared before the newcomers realized that they were pidgins." 
interpreter who spoke Fiote (as Kikongo was sometimes called, in this case possibly the Vili dialect) and a bit of English. Since his name was Antonio, we wonder if he also knew some Portuguese. So we see that there were workers who spoke some form of English and Portuguese, presumably pidginized in many cases. All of these could have introduced isolating features to the language they were unconsciously creating. ${ }^{12}$

\section{BANGALA (LINGALA)}

The grammars of Kituba and Bangala are very much alike. ${ }^{13}$ Their source languages are, of course, both Bantu, but this fact alone does not account for their great similarities. It seems as if the same sociolinguistic process produced both of them and that they differ largely because their vocabulary sources were different.

Bangala is what the language was called in the nineteenth century. It was also referred to as the commercial language, and in one case at least as "congolais" (Compagnie n.d.). Lingala was the name given it by

12. This historical critique of Mufwene's argument should not be taken to imply a rejection of his general thesis about the roles of substrate and universalist explanations for Kituba and Lingala. I ton believe that both have to be invoked for this or that phenomenon in specific cases. If we take Mufwene's "Bantu speakers" to include Africans from the east coast (the Zanzibati, as they were called), we might conclude that he still has a point. But the argument cannot be left with citing the presence of a certain number of east Africans; it would have to go on with demonstrating why these would have had a more important role in creating the pidgins than did those who did not speak a Bantu language. With respect to the quotation from Mufwene in this paragraph, one must excuse the following (Thomason and Kaufman 1988:29) as being ill-founded: "...Bantu-based pidgins [citing only Kituba and Fanagalo] owe their morphosyntax primarily to the Bantu languages spoken by their originators." However, I agree that what Bantu morphosyntax there is in Kituba and Lingala is due to the typological uniformity among the indigenous language (see 1988:184). For the kinds of non-Bantu linguistic features one must consider in understanding what happened in the origin of Kituba see Claudi (1988).

13. "[The dialects of Kituba] can all be characterized as being made up of a Kikongolike vocabulary with an essentially Lingala-like grammar, lined with French borrowings" (Fehderau 1962:xi). (I am not aware of any support for this statement from comparative studies. In any case, what is really being said? Does Fehderau imply, for example, that Kituba's grammar is more like that of an equatorial language than it is of one of the Kikongo dialects?) A useful comparison of the two languages is that of Eliet (1952). The similarities are seen in this example from the chapter on the adverb, chosen at random ( $p$. 49; the indexing is his): ' $\mathrm{Je}^{1}$ vous $^{2}$ considere ${ }^{3}$ comme $^{4}$ mon $^{5}$ meilleur ${ }^{6}$ ami $^{7}$, $-\mathrm{Na}^{1}$ ko kamata $^{3}$ yo $^{2}$ lokola ${ }^{4}$ ndeko $^{7}$ ya ngays ya monene ${ }^{6}$ (Lingala); $\mathrm{Mu}^{1}$ ke baka $^{3}$ nge $^{2}$ mutindi ${ }^{4}$ pangi $^{7}$ ya munu' ya nene ${ }^{6}$ (Monokotuba). Knappert (1979) found only 196 words of van Everbroeck's dictionary (1956), that is, $4.6 \%$ of its content, identifiable with those in Kikongo, without citing the dictionary he used for the latter language. He makes no reference to Kituba. The pidginized features of Kituba are characterized by Ayibite (1983) and Mufwene (1988). 
the Catholic missionaries at the turn of the century when a grammar was written. As missionaries worked on it, Egide de Boeck for the Catholics and Walter H. Stapleton for the Protestants, it was made to conform somewhat to the indigenous languages. ${ }^{14}$ In this way was developed literary Lingala, as found first in mission publications. It is still different from the language that is current among the people, which might be called the colloquial or vernacular variety by contrast. This variety is simpler in grammar. For example, adjectives are invariant; they do not agree in number and class with the noun. In any case, the number of noun classes has been reduced drastically. This is what we expect when a language is simplified in the circumstances that characterized the history of Bangala. An even simpler version of the language occurs in northeast Zaire. There it is still called Bangala.

We shall proceed in this section by first documenting the earliest recognition of a jargon or pidginized form of specch, then relate this idiom to Lobangi, and finally consider claims about its putative predecessor, a precontact lingua franca.

\subsection{The Bangala jargon}

The existence of an emergent pidgin is documented for the latter part of the 1880s. The evidence is as follows (see also Dhanis [1895]:28).

The earliest record is a statement by Fr. Emeri Cambier, writing 31 December 1888 at the Scheut mission Berghe Ste. Marie at Kwamouth. These are his words: "Quant a la langue qu'on parle dans ces parages,

14. Missionary linguists admit to having done this: "nous nous sommes toujours efforces de ramener progressivement le lingala à sa [presumably original (wjs)] grammaire" (de Boeck 1920:10). From this statement we deduce that the pidginized variety of the language was a widespread phenomenon. This work is not the first by de Boeck (b. 1875); see also 1904. One might be led to conclude that the grammatically more complete forms of Lingala are the product of this 'reconstitution' of the language, a view that is unpalatable because of its colonialist implications. That aspect aside, one wonders if missionaries had the means to propagate their model (or models) of the language among enough people to determine its present state. Since the history of Lingala, informed by a study of the use of the language by missionaries and the colonial government, has not yet been written, we must postpone committing ourselves to strong positions on this matter. A full account of Lingala must, of course, try to explain where the more developed (or rather the less simplified) versions of Lingala came from or how they came into being. The easiest explanation would be that there was an ethnic group, different from the Bobangi, whose language is perpetuated in Lingala. It has been argued by some Zaireans, indeed, that there were- - or are-people who should be recognized as Bangala. The issue is addressed in Samarin (1989a); on the creation of ethnicities in Zaire for political purpose see Harms (1987). For creolization (in the sense used by Thomason and Kaufman 1988) see below. 
voici ce que j’ai appris. Dans les deux villages qui nous séparent du Kassaï on parle le Bassenger qui est un mélange incompréhensible de diverses langues." 15 One deduces from this statement that a variety of speech was identified by whites that was unlike ethnic languages with which they were familiar. Its chief characteristic was that it contained elements from several languages. One might say that it was a mixed jargon. This is sufficient reason to suppose that it could have been the emergent Bangala pidgin.

It would appear that Fr. Cambier's mixed idiom (and possibly a jargon in the strict sense) was a very local phenomenon. It was spoken, he observes, by people at only two local villages. ${ }^{16}$ These villages were, of course, on the banks of the Congo River. The missionary is entirely wrong in his designation of the people who were supposed to have spoken this incomprehensible language. There was no ethnic group by the name Bassenger. This is in fact the French spelling of the Swahili term for designating black pagans, a word that in central Africa took the form basenji. ${ }^{17}$ This missionary, and possibly other whites, obviously

15. The letter goes on immediately as follows: "A Kwamouth et le long du Kassai on parle le Bateke (très difficile à apprendre). —- Au village qui est au dessus de nous, (du côté du nord, de l'équateur) on commence à s'exprimer en Bangala. Notre chrétien Thomas, avec son bas-Congo ne sait se faire comprendre et ne comprend rien au langage ni des Batékés ni des Bassengers ni des Bangalas. Il se peut que je me trompe, mais pour vous parter franchement je ne vois pas la moindre utitité pour ici du moins d'etudier a Scheut [the mission in Belgium] le Bas-Congo. _ Il me semble d'ailleurs que huit jours de pratique valent mieux que 8 mois de théorie. —_ et si l'on veut étudier une langue a Scheut mon humble avis serait qu'on étudiat le Kissouaili [Kiswahili] qui est comme une langue diplomatique (si diplomatie il y a) de tout le Congo et que comprennent tous les chefs de villages un peu importants. Il est à noter aussi que ces langues du BasCongo, des Batékess[,] des bangalas diffèrent complètement quoique offrant peut-être la meme origine." It is to be noted that the name Bangala is used by Fr. Cambier of an ethnic language. He must have been referring to Lobangi, for the missionary Dr. Aaron Sims wrote on 29 January 1889 that "The Kibangi commences at Kwa mouth" (American Baptist Historical Society, Rochester, New York. Microfilms, Foreign Missions, Reel 86). Everything Fr. Cambier had learned about the linguistic situation at Kwamouth must have been gathered from other whites. He had arrived there only a few weeks earlier, 24 November 1888, to be exact, six days after having arrived at Leopoldville (now Kinshasa), and just two months after setting foot at Banana on the coast (Mariaule 1952). A photocopy of Fr. Cambier's letter was provided me by Fr. Marcel-B. Storme from the Archives Centrales de la Congrégation de l'Immaculé Coeur de Marie [ClCM, Rome] F/VIII/b" 2 , addressed to "Monsieur le Superieur."

16. Because of Fr. Cambier's inexperience at the time he had made these linguistic observations, he could not have known that the jargon was to be found at other sites where frequent contact was made with the local peoples by the colonizing forces. That such was the case is something I take as quite reasonable.

17. The word has its origin in Arabic senj, 'black' for the color and as a name for Africans. Basanzl is widespread in central Africa, where its meaning is generally denigratory, occurring even in Sango (bazanzi in the singular). I do not agree that in central Africa 
picked up the name the Zanzibari soldier-workers used of the local people. ${ }^{18}$

The second statement is that of John Weeks (1913:48), the founder of the Baptist mission at Monsembe in August of 1890 (Missionary Herald 1893:264):

On the main river there was a mixed language, commonly called among us the "trade language"; by means of this lingua franca we were able to make ourselves understood at the various places at which we touched on our search for a new site, and it stood us in good stead during our early days among the Monsembe people. There was a large element of Bobangi in it, some Kiswahili words, and a few Lower Congo words and phrases. ${ }^{19}$

This statement is complemented by that of W.H. Stapleton who wrote (Missionary Herald 1892:226) that when missionaries arrived at Monsembe, a short distance downriver from Bangala (Nouvelle Anvers, now Mankanza), they found its inhabitants speaking a "miserable patois of Kilolo and Kibangi."

Another person engaged in trade to the west of Monsembe had something similar to say about the language (Compagnie n.d.5): "La langue commerciale n'est pas une langue propre, mais un assemblage de mots qui ont le plus frappé les indigènes commerçants voyageurs."

\subsection{The usefulness of Lobangi}

Support for the hypothesis that Lobangi, in one or more of its several varieties, served as the basis of the Upper Congo's lingua franca comes from statements about how useful this ethnic language was in central Africa. I should like to argue that it was the language of the Bobangi that was used in the earliest stages of colonization, because these people were willing to work for the whites. They had commercial bases at different places on the Congo and Ubangi rivers, and they had a large number of slaves-indeed, their trading firms relied heavily on slaves (Harms 1981).

Let us consider some of the statements made concerning the early years of colonization. It was a Bobangi who served George Grenfell in

Zanzibari washenzt simply meant 'villagers' (Fr. Bontinck, personal communication, 19 December 1988). For a discussion of this word see Bontinck (1985) and Tolmacheva (1986). 18. The recruitment and employment of east African recruits are topics treated in Samarin $(1989 a)$.

19. John Henry Weeks (1861-1924) served at San Salvador from 1882-1888 and at the Underhill Mission from 1880-1890 (The Baptist Handbook 1926:334). 
October 1884 "to appease the fears of his countrymen" (Johnston 1908(1):117). Even at Bangui, out of Bobangi sphere of commerce, as far as we know, Maurice Musy, the chef de poste, was learning Lobangi from some of his workmen in the latter part of 1889 and early part of 1890 , presumably because of the number of Bobangi working at the French post. As early as 1884 Johnston wrote (1884:477) that "Ki-yansi [another name by which the language of the Bobangi was known] is the prevailing language on the river from the mouth of the Wabuma to the Equator." And in $1887 \mathrm{~W}$. Holman Bentley wrote of Lobangi (Missionary Herald 1887:433), "if I speak this dialect, I shall be understood everywhere." ${ }^{20}$ A few years later a missionary at Bopoto wrote (Missionary Herald 1891:320): "Kibangi is the chief language of the Upper Congo. If a traveller knows Kibangi, he can make his wants understood at most towns between here and Stanley Pool." This is supported by a statement by another missionary (Missionary Herald 1896:270) that at Bolobo there were men engaged as workers who had come from Bopoto, Monsembe, Bonginda, Lulanga, the Equator, and Lukolela, all speaking a variety of languages; "but all understand some Bobangi."21 As evidence that it was not only missionaries who were making such statements, we note that a similar remark was made by a Belgian: from the Kasai River to Nouvelle Anvers "la langue usitée est le ki-bangi" (Chapaux 1894:568). ${ }^{22}$

\subsection{Linguistic basis}

It has been seen why Lobangi might have served as the basis of a contact language. Here we only want to consider at least evidence for this observation. ${ }^{23}$

Although Fr. Cambier, cited above, did not relate the mixed idiom to any specific ethnic language, his contemporary, the Baptist missionary John Whitehead, did (1899:vi): "[The Bobangi language is] the basis of

20. Of course, we are not obliged to take too seriously his statement that he could be understood "everywhere". He could only have been writing about the places where he chose to stop. They were undoubtedly certain kinds of places, such as government or trading posts and villages where food and firewood could be purchased. In any case, another missionary, as we saw, remarked only that he could be understood at "most towns."

21. The history of the linguistic aspects of Protestant missions on the Congo River, with particular reference to Lingala, is treated in Samarin (1986b); also Samarin (1989b).

22. This is a necessarily brief summary of the role of speakers of Lobangi in the colonization of the Congo and Ubangi river basins, but a full account would take us beyond the scope of a paper such as this.

23. Bokamba (n.d.:1f) seems to doubt the Lobangi basis of Lingala, pointing out that many languages contributed to it. 
the eclectic 'trade' language used by the officers of the Congo Independent State, by traders and other travellers, and further copied from them by the strangers from other parts of the Congo brought to the various posts and stations to act as servants and labourers."

One study of Lingala's lexicon (Knappert 1979) arrives at the conclusion that it is similar to Lobangi's in over $30 \%$ of the cases. As a matter of fact, $56 \%$ of the words in Guthrie's dictionary (1939) are found in Whitehead's dictionary of Lobangi. The figure only drops to $34 \%$ when van Everbroeck's dictionary (1956) is compared, a fact probably due to the varieties of Lingala that were used in this work.

Using twentieth-century dictionaries of Lingala is not the best way to proceed, however, if we are interested primarily in the origins of the language. We should use nineteenth-century word-lists. Only one is in my possession, a copy of Compagnie, probably duplicated in the $1890 \mathrm{~s}^{24}$ Taking twenty verbs and twenty nouns, the latter being names for parts of the body, and comparing them with words in Whitehead's dictionary, I find that there are twelve noun cognates and nine verb cognates. Comparisons with Iboko (Cambier 1891), the language around the post of Bangala, and Lomongo (Hulstaert 1952, 1957) revealed even fewer cognates, especially the latter. ${ }^{25}$ With respect to the former, it is interesting to observe that it has dj before a vowel whereas the "trade language" has li: e.g. djinga and linga 'want, like, love' respectively. The languages differ also in that Iboko has $\mathbf{i}$ for a class prefix whereas the trade language has li.

We must, of course, not imagine that the language of the Bobangi was uniform. For just the Nunu and Moyi group-in the nineteenth century identifed as Bobangi, located roughly between Bolobo and Yumbi, a stretch about fifty kilometers long-it has been found that there are three separate dialects that have less than $80 \%$ correspondence to one another (Harms 1987:99, citing a personal communication from

24. It is very similar to Wtterwulghe (1903), which was preceded by a publication in 1899. Obviously one is based on the other, or both of them are based on a work which has disappeared or is not yet known.

25. Fr. Hulstaert has suggested $(1940: 37,38,43,67,69,70)$ that Lingala is a sort of pidgin or "broken" Lomongo with an admixture of riverine speech, e.g. Loleku (presumably the indigenous language of the area from what is today Mankanza) and Lobangi. Unfortunately, the assertion is not supported by adequate linguistic evidence. Nonlinguistic evidence would also be required. We would like to know the extent to which speakers of Lomongo were in the work force of the Belgians in the nineteenth century, when Bangala, as we suggest in this paper, was being created. Given the fact that large numbers of slaves came from the Mongo area to the Congo River, one speculates that these people may have introduced Lomongo words into the pidgin that they were acquiring. The role of slaves and 'Bangala' in the work force of the Congo Free State is treated in Samarin (1989a). 
Jan Vansina, reporting data from the Musée Royal de l'Afrique Centrale, Tervuren, Belgium). According to F.K. Erhard Voeltz (personal communication), who has some familiarity with the area, determining the source or sources of Lingala might be a daunting task, given the great similarity between the languages of the Zaire River basin and of the area between the Ubangi and the Zaire rivers. This is illustrated by comparing translations of the sentence "Moi, je vais au village construire une maison" (Dzokanga 1979:6-7):

Bobangi: Ngai, nakoke o mboka notonga ndako.

Nunu: Ngai, namoke o mboka notonga ndako.

Libinza: Ngai, nakakende o mboka nakatonga ndako.

Lusakani: Ngai, namoke o mboka notonga ndako.

Mpama: Ngai, nakei mboka otonga ndako.

Liboko: Ngai, nakei o mboka nakatonga ndako.

Loyi: Ngai, nakei mboka natonga ndako.

Impfondo: Ngai, nakei o mboka mpfoa ya itonga ndako.

Enyele: Nga, nakei mboka botonga ndako.

Bomitaba: Nga, nakei mboka eke otonga ndako.

Likuba: Ngai, nasoke mboka otonga ndako.

Likuala: Nga, nake o mbowa notonga ndao.

Moyi: Ngai, nakeke o mboka motonga ndako.

Mboshi: Nga, izwa mboa otonga ndai (ndao).

Koyu: Nga, lizwa mbooka etonga ndako.

Makua: Nga, ikendi mboga etonga ndago.

Bongili: Ngai, nake mboka na kotonga ndako.

The task is going to be made all the more difficult by the fact that people are borrowing from Lingala into their vernaculars, as I observed in 1988 at Limpoko, among Bamwe speakers of a related language. (Since in this paper we are not addressing ourselves to the task of determining the linguistic sources of Lingala, no references are being cited for the nineteenth-and early twentieth-century works on relevant languages.)

\subsection{Lobangi as lingua franca}

It has been claimed that Lingala had its origin in a lingua franca used by people on the Congo River before whites arrived in the 1880 s (e.g. Ngalasso 1986:17). These claims are made, as with Kituba, on the basis 
of the trade that was carried on between different ethnic groups. Thus (de Boeck 1920:7-8):

Remarquons que les principaux articles de commerce étaient des femmes et des esclaves, articles "parlants", et on comprendra aisément que les communications entre tribus, la polygamie-exogamie et l'esclavage sévissant sur grande échelle, devaient logiquement amener un plus grand rapprochement, et, a la longue, une fusion entre les divers dialectes. Aussi bien paraît-il qu'une espèce de langage commercial commun existait déjà avant l'arrivée des Européens. ${ }^{26}$

All such contemporary claims about Bangala are mere assertions. What is the evidence? We are closer to the facts when we consider what Whitehead said in the last century $(1899: \mathrm{v})$. After describing the distribution of the Bobangi, "their slave descendants, and the strangers who have come to dwell in their midst and speak their language," he mentions a number of "other tribes in the Bobangi area..." These, he says, "use the Bobangi language as a common means of intercommunication, and more or less among themselves."

Taken at face value Whitehead's observation constitutes "proof" that Lobangi was a lingua franca in the technical sense at least in the riverine area on each side of the equator. But one can also come to a different conclusion. That is, Whitehead's observation of communication going on in Lobangi in this area, assuming for the moment that it was correct to some degree, might only be evidence of a certain amount of intercomprehensibility between the languages. Unfortunately, we do not have sophisticated linguistic evidence of this state of affairs, but Knappert

26. It should be noted that de Boeck is using trade to explain both the similarity between the varieties of speech found along the Congo River upriver of Stanley Pool and the emergence of a commercial language. For my part, I would conclude that linguistic similarity would lead to a great deal of bilingualism. It is possible, of course, for close varieties (dialects in many cases) to be levelled, as was the case with koine Greek. The difference between language evolution in the eastern Mediterranean and central Africa is that in the former case an empire was being created with a polyglot military force moving among people of entirely different languages and in the latter people made normal contact with each other. We should also be incredulous about the implied suggestion that intermarriage was a factor. Some must have certainly gone on, but not necessarily on a grand scale. Harms, for example, notes (1987:225) that in the old days the Bobangi and Nunu seldom married each other. Another who assumes, naturally without historical, anthropological, or linguistic argumentation, "besoins commerciaux ou politiques" in the creation of "langues 'passe-partout"-apparently in the precontact era-is Georges Bruel, who arrived in central Africa in 1896 at the age of 25 . But what he says about the spread of these languages might be interpreted as dealing really with their creation: "Peu a peu, ces sabirs se sont répandus un peu partout à la suite des soldats, des conquérants ou ont été propagés par nos Sénégalais, par nos gardes indigènes, par nos employés de commerce noirs, par nos traitants, par nos travailleurs ou par nos commerçants indigenes" (Bruel 1935:164-65). 
(1979:154) suggests that it is the case: "The inhabitants of the fishermen's villages along the Middle Congo, the lower Ubangi and Giri (i.e. Ngiri) rivers, the lower Lulonga, Mongala, Likwala, Sanga, Tumba, Ruki and Ikelemba rivers, all speak closely related dialects, to the extent that they do not have to resort to another language when conversing together. This applies to the Bangi, the Ngala, the Eleku, Nkundo, Mongo, Ngombe, Ntomba, Mabale, Libinza and Losengo." (See also Vansina 1984.) ${ }^{27}$ This does not seem to be the kind of sociolinguistic context in which a real lingua franca would arise; for that one expects a high degree of linguistic diversity. Here one would expect dialect levelling or linguistic convergence. But a linguist's expectations cannot be based on linguistic facts alone. Equally important are ethnographic ones, like those provided by Harms on the Bobangi and Nunu.

We also have to question the validity of Whitehead's observation on the basis of methodology. How, we ask, did he arrive at his conclusions? To ascertain the facts he would have had to identify the native languages of a good number of people and which ones they were using with each other. In short, he would have had to do what we expect people to do in our own period. We ascribe credibility only to those studies where sociolinguistic observation is carefully controlled. Whitehead must surely have had some reason to arrive at his conclusion; the challenge we face is to try to determine what it was.

Finally, it should be observed that nowhere else do we get the impression that Lobangi was a real lingua franca in the 1880 s. Evidence already cited for the usefulness of this language only corroborates, in my

27. A different impression is given by Whitehead (1904:49): "Grammar comes in to play skittles with words which may have similar meanings, as, for instance, a Bobangi Subjunctive Present is a Lomongo Indicative Present and an Mpama Indicative Past, and in Monsembe something else, I believe. The Lomongo Indicative Future Indefinite is the Mpama Indicative Present. The Indicative Present in Monsembe is the Mpama Indicative Perfect with a strong stative effect. The Bobangi Indicative Past is in Mpama always retoned to signify the Indicative Future Definite. The Bobangi Subjunctive Present Continuative is the Mpama Indicative Past Continuative and the Lomongo Indicative Present Continuative. In the Negative constructions there is a lively perplexity. In Bobangi the Negative construction is like two jaws of a vice and grips all that comes between. In Lomongo I see the Negative gets in among the Tense Formative and upscts them a bit." This observation does not constitute counter-evidence in my opinion. Whitehead was comparing languages that are more distantly related than those in the area where he thought he observed the pervasiveness of Lobangi. Coquilhat's remarks (1988:353-54), moreover, are too superficial to carry much weight in the present context: "Le dialecte des Ba-Ngala est en réalité très distinct du kibangi. Même des mots employés pour la numération sont différents, ce qui esı caractéristique... Le dialecte kingombé esi encore bien plus différent. Les Maroundja ont aussi leur Jangue à eux." 
opinion, information of other kinds: namely, that Bobangi trading firms were widely implanted on the Congo River.

We seem to be left with no evidence for a precontact lingua franca on the Middle Congo, but everything was ready for the emergence of one, pidginized or not. Two factors, I should like to argue, brought it into existence. The first is arrival of hundreds of foreigners who needed such a language in a hurry. The second is the intensive movement of indigenous peoples. Central African rivers became veritable highways of population movement in the $1880 \mathrm{~s}$ as part of the process of mobilizing them in the work force. And colonization created multiethnic centers of several kinds: administrative posts, trading posts, military training centers, and missions.

\subsection{The sociolinguistic context}

If there were no lingua franca on the Middle Congo but widespread knowledge of Lobangi in one of its several dialectal forms, what led to the emergence of the pidgin whose existence has already been documented? Of course, those who believe in the existence of a 'trade language' can simply say, as does de Boeck (1920:9), for example, that it was "corrompu" when it spread throughout the colony, producing the "jargon" he calls "bangala commercial". (This resembles Diki-Kidiri's hypothesis about the history of Sango. Reasons for rejecting it are given in Samarin 1985b.)

Whitehead, we saw above, assumed that Europeans created "the eclectic 'trade' language" and that their employees, presumably African, copied their way of talking. He even says (1904:50) that this new language was identified by the indigenous people as the "white man's language" or "Bulamatale" (quotation marks are his). But we also saw above that another European believed the lexicon at least was put together by the "indigenes commerçants voyageurs".

There is no doubt that Europeans were using a pidgin or a pidginized form of language to communicate with the indigenous people, especially those who were employed by them, as Whitehead correctly observes. For example, in 1894 it was estimated that 1,200 riverine people, identified as Wangata from the equator, Lulanga, and Bangala, were serving on the steamboats (Lemaire 1984:181). But is it correct to assert that whites were exclusively or principally involved in the creation of this new language? Were Africans only imitators of the way whites communicated? To some degree, yes. Indeed, by 1904 indigenous people, according to Whitehead (1904:50), were already embellishing their speech with "quotations" from this pidgin. But that does not necessarily mean 
that they were imitating whites. It is much more likely, I believe, that they were imitating the Africans who represented the whites, for they too stood in a position of power over the local people.

But in this instance again Whitehead is not to be taken as an omniscient and infallible source of fact and interpretation. We should note, for example, that he says nothing about the thousands of African employees who were not indigenous to central Africa. These were brought from other parts of Africa, most of whom would have had some experience in trying to communicate with words and constructions from languages found in the Lower Congo. These are the ones, I would like to argue, who had an important role in the creation of Bangala, a role that was more important than that of whites. In support of this thesis we need, for the moment, only invoke a fact that cannot be controverted: that it was these foreign workers who had the greatest amount of contact with central Africans. Indeed, these African employees were the ones who got things done. Field colonialism succeeded because of them.

These workers, frequently considered as consummate "linguists" by their employers, must have been the sources for the linguistic data that whites compiled. One of these, by way of example, might have been the Egyptian corporal who served as "court" interpreter. He is said to have spoken Arabic, English, Fiot (that is, Kikongo), Bangala, and Swahili (Le Congo Illustré 1895:15). How else did whites fill out their word-lists? Using English or French (or possibly Swahili) with a Kru, Senegelese, or Zanzibari, they elicited the words and phrases they thought they would need. This manner of proceeding was used by Lemaire (1897). The point here is that whites were not going directly to the local people, with whom they had no language in common, to build up their wordlists. They used their employees, who had themselves arrived at some understanding of the local languages. This is one reason, I believe, why the pidgin was so mixed.

To illustrate the sociolinguistic setting in which foreign African workers had to communicate, let us go back to Fr. Cambier's comments about the villages near Berghe Ste. Marie. They document the presence of a mixed jargon at a center of colonial activity only a few years after whites had come into the area. The station at Stanley Pool was being founded in December 1881 by H.M. Stanley. Mswata, just twelve miles downriver of the confluence of the Kwa River with the Congo, was the next station founded, in February 1882 (Alexis 1890). And there was a post at Kwamouth in 1885. Contact between the expatriates and the indigenous population must have been active and intense. Communication would have been necessary for getting firewood for the steamers, but what was always needed in large amounts was food. The memoirs 
of whites from this period reveal how dependent the colonizing forces were on local people for subsistence.

It would be a serious mistake, however, to reduce the sociolinguistic situation to the cliche of "trade", something of which contemporary writers are as guilty as earlier writers werc. There must have been many other kinds of relations for which language was necessary. One that has hitherto been entirely ignored in understanding central African history is the relations established between men and women. Although we cannot at this time describe what they were and how they might have figured in language creation (but see the chapter on women in Samarin 1989a), we must document the fact that at Kwamouth in 1885 there was a "house for the women of the station" that was separate from the row of workmen's huts (Batemen 1889:16). ${ }^{28}$ There is reason to believe that both men and women were of different ethnicities. Some of the men would have been foreigners, others at this date already from other areas of central Africa. The women, on the other hand, were probably not from east or west Africa. (Although Stanley had some women on his expedition when he crossed Africa from east to west, there is no evidence that there were any in subsequent groups.) Nor were they probably local women. If they were, they would have been living in their own villages. That they were being housed reveals that they had come from somewhere else. The movement of women from one place to another by agents of the Congo Free State is easily demonstrated. Although their role is never made explicit, we can assume that they performed domestic chores, like preparing food. But it is not unlikely that they were at Mswata also, or primarily, as sexual partners for the colonizers' black personnel. In other cases we read of members of the work force, as well as the militia, having "wives".

It would also be a mistake to focus narrowly on Kwamouth for an explanation of what Fr. Cambier learned about the local jargon. Between 1882 and 1888 many trips had been made by whites-agents of the Congo Free State, traders and missionaries-on the Congo River. Stations had been established upriver, and a lot of contact had been made with speakers of Lobangi. Therefore the foreign African personncl of the whites would have done at Kwamouth what they were doing elsewhere on the river, using the languages they knew whilc adding what they were learning of the indigenous languages, principally Lobangi.

The strategy of these workers is suggested by Fr. Cambier's statement about the knowledge that chiefs of important villages had of Swahili.

28. Bateman had been a captain and adjutant of the gendarmerie in the Congo Free State. 
The Zanzibari, who made up an important part of the Congo Free State work force in the $1880 \mathrm{~s}$, seeing, as I assume, that the local languages were similar to the Swahili they had brought with them from the east coast, would have tried using it as much as they could. It was actually observed that "Zanzibaris can often make themselves understood in conversing with the natives" (Johnston 1883:581). ${ }^{29}$ When Swahili failed, as it must have in many if not most circumstances, the Zanzibari resorted to any other Bantu language they had become familiar with. The most important source would have been some variety of Kikongo and the Kiteke they would have acquired at Stanley Pool. It was no wonder that the jargon at Kwamouth was mixed.

\section{LINGUISTIC EVIDENCE}

In this paper we have presented all the historical data now available about the origins of Kituba and Lingala. Within the confines of a journal article a new hypothesis of their origins has been presented: That foreign African workers had more to do with the creation of the earliest forms of these languages than did Europeans. The argument for this hypothesis would be stronger if there were linguistic evidence. Of considerable significance, for example, would be vestiges of foreign African languages in Kituba and Lingala. No one, to my knowledge, has studied their vocabularies for such evidence. However, we have cited the fact that Swahili words are found in considerable numbers. Although their significance to understanding the origins of these lingua francas has not been fully perceived, they confirm what we know by other means: that Zanzibari played an important role in the colonization of central Africa.

The case is clearer for Sango. As a result of the importation of workers from the equatorial area and from the Lower Congo, as it was called, many words of Bantu origin became integrated in Sango, a Ubangian language. One of these is the copula, yèke, which appears to come from some variety of Kikongo (Samarin 1986c) and which has had a grammatical impact on the language. Bantu-speaking Africans were, of course, foreign in the Ubangi basin. As for West Africans, they appear to have left two words. A rather clear case can be made for the word for 'money'-recorded in the nineteenth century as kinja, today having the

29. Whites also recognized the similaritics between central Africa's Bantu languages and Swahili and even "Kaffit" (e.g. Coquihat 1888:354; Johnston 1883:581). Coquilhat speculated, in a rather far-fetched sort of way, about a language-contact explanation for lexical similaritics: "Mais ne sont-ce pas des termes introduits par l'usage du kibangi dans les relations commerciales?" (1888:354). 
form nginza. It has been traced to Loma, and probably was brought to the Ubangi basin by people from Liberia rather than by Senegalese (see Samarin 1989c). Since one finds "dans la région de la Lukenie" the word kundja "une sorte de fer de lance ébauche" once used as currency (Mahieu 1924:22-23), there is good reason to believe that this same West African word also remained in Zaire. (If this is true, it would constitute one small trace of West African presence in Bantu-speaking central Africa.) The other word is the one for 'work', in Sango today kwà.

One is entitled to ask why West African languages did not leave a greater imprint on Kituba and Lingala than they appear to have done. ${ }^{30}$ (We have, however, noted the possibility of their having created Kituba's isolating features.) The answer probably lies in their diversity. West Africans were ethnolinguistically very heterogeneous, even the ones called Sénćgalais in French. Finding themselves together in a caravan, on an expedition, at a military or trading post, or at a mission station, they had to communicate with each other at the same time they were trying to communicate with the indigenous peoples. As memoirs and colonial archives make clear, there were very few who spoke any European language, although 'broken English' is frequently cited. Finding themselves in small numbers throughout the area, they therefore could not have the same kind of impact that a large, monoglot work force would have had. This makes sociolinguistic sense. Therefore what they did, probably very quickly, was to adopt a means of communicating that was based on the indigenous languages, in other words, create a jargon that was soon stabilized as a pidgin. (The reason that there are so many Bantu words in Sango is probably duc to the fact that both foreign and

30. Thomason and Kaufman discuss a number of pidgins with features that are foreign to the lexicon-base language, stating their case as follows (1988:192): "if there is clearly a [target language, as there was on the Ubangi River], or if speakers of one language or language group are especially numerous or prestigious-to give just two examples-then the grammar of the pidgin will reflect thosc social facts by having a disproportionate number of features from one or more particular source languages [sic]." A language they have overlooked is so-called Chinese Indonesian (Dreyfuss and Oka 1979). This is a variety of Indonesian that is spoken by the Peranakan, descendants of Chinese traders who began settling in large numbers in Indonesia from as early as the seventeenth century. The language has Javanese features, because the Chinese intermarried with Javanese women. There are also Chinese features, as one might expect: pronouns, numbers, and cultural terms, as well as remnants of the influence of the phonology of some Chinese language. This case is not similar at all to the one in central Africa, for in Indonesia the foreigners were ethnolinguistically much more homogeneous. 
central African workers were using the early forms of Kituba and Lingala.) $)^{31}$

We must conclude therefore that although West Africans were in position of power and authority over the central Africans, dressed in a European manner and in many cases armed, they did not present an identifiable and consistent linguistic target to the people with whom they dealt. Their communication needs-and the colonial imperatives- led to the suppressing of their own languages (except with their co-ethnics, of course) and the targeting of the immediately accessible ones.

In opposition to the number of statements that have been made about the existence of contact languages before the arrival of whites in the nineteenth century we have the following about what foreign African employees did. It too might be purely speculative on the part of the European making it: however, here there is slightly more reason to believe that it may be based on observation. It would appear, as is demonstrated elsewhere (Samarin 1985b), that the jargon being created around Bangui was apparently a Banda or Ngbaka one and not Sango, which soon dominated the area: "Nos hommes avaient peu a peu réuni quelques mots à l'aide desquels ils avaient constitué une sorte de patois, qui leur permettait jusqu'ici de se faire facilement comprendre des indigènes" (Brunache 1894:207).

\section{CRFOLIZATION OR PIDGINIZATION}

If pidginization has been considered a factor in the origins of Kituba and Lingala, this is because the pidginized features of these languages have been recognized; in the latter case certainly with the form known

31. I take the following statement as providing evidence about the Bantu words that were being used by African personnel in the Ubangi basin: "La langue ndri est parlée, avec quelques différences de dialecte, par les Banziris, les Togbos, les Langouassis, les Ndris, et est comprise en partie par les Mandjias, les Aouakas, les Akoungas, jusque chez les Arétous. Elle a de nombreux points de ressemblance avec les langues de la côte orientale, kiswahili et kiganda" (Maistre 1895:288). This report, published less than ten years after whites had arrived in the area, is undoubtedly wrong about a "Ndri" language, presumably belonging to the Banda family, being widely understood by people speaking languages of the Gbaya-Ngbaka and Gbanzili families of the area, both along the Ubangi River and in the hinterland to the north. And no Banda language of the Central African Republic can be said to have an obvious resemblance to any Bantu language whatsoever. $\mathrm{He}$, as well as other whites, got Bantu words, I believe, from the workers who spoke some form of one or more Bantu language. Given the well-established fact that in 1895 whites still had very little contact with Ubangians on the river and practically none with those further inland (Samarin, forthcoming), it is hard to believe that the indigenous population had already picked up Bantu words from the African workers of the whites. 
today as Bangala. There is also more justification for calling the latter Bangala a pidgin. However, we must recognize that good evidence of a linguistic nature for the existence of pidgins (in the strict sense of the term) in the Lower Congo and Middle Congo (that is, the equatorial area) cannot yet be cited. As Thomason and Kaufman perceptively observe (1988:173), "a process of linguistic negotiation need not presuppose a target language..." Or one might say that people do not need a language to communicate with each other; they can do so with a variety of linguistic means. Therefore, it would be presumptuous to declare where and when anything as stable as a pidgin came into being in the last two decades of the nineteenth century. Nonetheless, I am inclined to believe that a viable although variable code emerged quite early in both regions of central Africa.

With Lingala we are faced, as we have observed, with a pidgin (Bangala), on the one hand, and, on the other hand, a variety of Lingala that cannot be properly called a pidgin. Given the fact that missionaries became involved quite early in the standardization of the lingua franca and began to use it in education (a history of which deserves to be written), we are justified in crediting these activities with some influence on Lingala. But the influence of foreigners through literacy and education, accessible to relatively few people, must have been far weaker than that of central Africans themselves. Colonization was labor intensive; people in large numbers-women as well as men, children and adults-were moved about at the will and whim of the agents of the Congo Free Statc. They must have found it useful to adopt the emerging equatorial lingua franca among themselves. It was also the lingua franca for the Force Publique, the militia of the State, which in the early years consisted of large numbers of foreign Africans.

It is therefore reasonable to consider the possibility that parallel to the emergence of a pidgin that became stabilized in the northeast, there emerged in the equatorial area a creolized variety. Creolization, as Thomason and Kaufman (1988) effectively argue, can take place without pidginization (that is, without a prior pidgin in its history; as a process, of course, pidginization can be said to characterize creolization). Chinese Indonesian, as has already been observed, can be cited as an example of this phenomenon-the creation of "abrupt creoles". This kind of creolization took place, we would assume, because the indigenous peoples responded favorably (a notion developed by Thomason and Kaufman 1988:192) to the grammatical devices that were being used by the foreigners invading the region. But central Africans outnumbered these foreigners, and they appropriated the new language for themselves, making it more congenial to their own grammars and lexicons. This, at least, is a hypothesis that should be seriously considered. 


\section{CONCLUSIONS}

An examination of the earliest references to lingua francas in central Africa leads to the conclusion that Kituba and Lingala probably arose in the period immediately after King Leopold II of the Belgians stimulated the exploration and occupation of the area. Assertions that these languages issued from established lingua francas earlier are speculative, being founded on nothing more than the assumption that trade leads inevitably to "trade languages". Although no necessary link has to be assumed between the two, since trade, as far as $I$ have been able to determine, can take place without "trade languages", it is not unreasonable to suppose that trading activities may have led to bilingualism in some form of Kikongo and Lobangi. It is, however, just as reasonable to suppose that members of a trading ethnolinguistic group learned the languages of their regular trading partners. It all depends on the nature of the trading relationships. ${ }^{32}$ In any case, whether or not Lobangi and a variety of Kikongo were known among people of other ethnolinguistic groups, we would have to explain how and when the pidginized varieties emerged.

Although I have argued against the belief in the existence of central African "trade languages", I do not claim to have disproven their existence. What I argue is simply that at the present state of knowledge we are justified in believing that a late nineteenth-century (post-contact) origin for Kituba and Bangala is more likely. ${ }^{33} \mathrm{~A}$ description of the work force of colonization would reveal the role of foreign Africans in the pidginization of indigenous languages and the creation of new languages. ${ }^{34}$

32. For example, we might find that the Bobangi of a certain location traded with the $X$ people, that those of another village traded with the $Y$ people, and so forth. But I do not find any evidence, one way or another, in Harm's monograph of the Bobangi (1981). 33. The topic raised here deserves serious attention on the part of linguists concerned with pidginization and languages-in-contact, who will undoubtedly have to draw from the studies of economic history and economic anthropology. Since the literature on this topic is so scant, it is worth noting Rhodes' paper on Algonquian trade languages (1982). He hypothesizes the existence of four koines, as he calls them also. He does not discuss the use of these languages in trade. We deduce from the paper that nothing like pidginization occurred. He does note, however, although without relating the fact to the paper's topic, that many speakers of Ottawa today admit to using a mixture of Ojibwa and Ottawa, something they call the Chippewa language.

34. Samarin (1989a) analyzes the colonization of Central Africa in terms of the work forces of the Congo Free State and the French I laut-Oubangui. My labor perspective on the history of pidgins makes me very critical of unwarranted characterizations of the kinds of relationships that are assumed for pidginization. For example: "In early colonial days the form of French spoken in Haiti by the slave population from Africa and the European 


\section{REFERENCES}

Alexis, M.-G. 1890. Les Congolais, leurs moeurs et usages: Histoire, geographie, et ethnographie de l'Etat Indépendant du Congo. 3e Edition. Liège: H. Dessain.

Ayibite, Pela Asey. 1983. Du kikongo au kituba: Un cas de pidginisation d'une variêté véhiculaire bantu. (Centre de Linguistique théorique et appliquée (CELTA), Lubumbashi) Africanistique 12:12-44.

Bailey, Henry. 1894. Travel and adventures in the Congo Free State and its big game shooting. London: Chapman and Hall.

The Baptist Handbook. 1926. (The Council of the Baptist Union of Great Britain and Ireland). London: Baptist Union Publications Department.

Bateman, Charles S.L. 1889. The first ascent of the Kasaï: Being some records of service under the lone star. London: George Philip and Son; Dodd, Mead and Co.

Bentley, H.M. 1907. W. Holman Bentley: The life and labours of a Congo missionany. London: The Religious Tract Society.

Bokamba, Eyamba G. [n.d.] Ekolongonelo ya Lingala: An introductory course (preliminary version). Urbana-Champaign: Department of Linguistics, University of Illinois.

Bontinck, F. 1985. L'étymologie du terme bosenji. Annales Aequatoria 6:210-13.

Bruel, Georges. 1935. La France Équatoriale Africaine: Le pays, les habitants, la colonisation, les pouvoirs publics. Paris: Larose.

Brunache, Paul. 1894. Le centre de l'Afrique: Autour du Tchad. Paris: Ancienne Librairie Germer Baillière et Cie.

Cambier, Emeri. 1891. Essai sur la langue congolaise. Bruxelles: Imprimerie Polleunis et Ceuterick.

Caprille, Jean-Pierre (ed.). 1981. L'expansion des langues africaines: Peul, sango, kikongo, ciluba, swahili. (LACITO-Documents, Afrique, 8). Paris: SELAF.

Chapaux, Albert. 1894. Le Congo: Historique, diplomatique, physique, politique, économique, humanitaire, et colonial. Bruxelles: Rozez.

Claudi, Ulrike. 1988. The development of tense/aspect marking in Kru languages. Journal of African Languages and Linguistics 10:53-77.

Compagnie des Produits de la Sangha et de ta N'Goko. [n.d.] Petit vocabulaire commercial français a l'usage des nouveaux amivants dans les régions occupées par la moyenne Sangha et la N'Goko.

Coquilhat, Camille. 1988. Sur le Haur-Congo. Paris: J. Lebegue et Cie.

de Boeck, Egide. 1904. Grammaire et vocabulaire du Lingala, ou langue du Haut-Congo. Bruxelles: Imprimerie Polleunis-Ceuterick.

- 1920. Cours theorique et pratique de Lingala. (Of which only photocopied pages of Preface have been seen.)

DeCamp, David. 1971. The study of pidgin and creole languages. In Pidginization and creolization of languages, ed. Dell Hymes, pp. 13-42. Cambridge: Cambridge University Press.

Dhanis, Francis. [1895]. Le district d'Upoto et la fondation du camp de l'Anwimi. Bruxelles: J. Vanderauwera.

Diki-Kidiri, Marcel. 1981. L'expansion du sango en Centrafrique. In Caprile (ed.), pp. 29-42.

plantation managers was obviously only a pidgin,...." (Nida and Fehderau 1970:146). What reason do we have for assuming that whites were in direct communicative contact with the slaves? The facts of exploration and colonization in Africa suggest that what was more likely was the role of bilingual bosses-probably themselves liberated slaves. 
Dreyfuss, Gail Raimi and Djoehana Oka. 1979. Chinese Indonesian: A new kind of language hybrid? Papers in Pidgin and Creole Linguistics 2:247-74. (Pacific Linguistics, Series A, 57.) Canberra: The Australian National University.

Dupont, Edouard. 1989. Lettres sur le Congo: Recit d'un voyage scientifique entre l'embouchure du fleuve et le confluent du Kassai. Paris: C. Reinwald.

Dzokanga, Adolphe (also known as Mwana-Mboka). 1979. Dictionnaire Lingala-Français suivi d'une grammaire Lingala. Leipzig: VEB Verlag Enzyklopädie.

Eliet, Edouard. 1952. Les langues spontanées dites commerciales au Congo: Le Monokouba comparé au Lingala et au Lari de la région de Pool. Brazzaville: Édition Victor Simarro.

Fabian, Johannes. 1984. Language on the road: Notes on Swahili in two nineteenth century travelogues. (Sprache und Geschichte in Afrika [SUGIA], Beiheft 4.) Hamburg: Helmut Buske.

- 1986. Language and colonial power: The appropriation of Swatili in the former Belgian Congo 1880-1938. Cambridge: Cambridge University Press.

Fehderau, Harold W. 1962. Descriptive grammar of the Kituba language: A dialectal survey. Preliminary Checking Edition. Leopoldville [Kinshasa]: American Mennonite Brethren Board of Missions.

- 1966. The origin and development of Kituba (lingua franca Kikongo). Ph.D. diss., Cornell University.

Guthrie, Malcolm. 1939. Grammaire et dictionnaire de Lingala. Cambridge: W. Heffer and Sons.

Harms, Robert. W. 1981. River of wealth, river of sorrow: The central Zaire basin in the era of the slave and ivory trade, 1500-1891. New Haven and London: Yale University Press.

- 1987. Games against nature: An eco-cultural history of the Nunu of Equatorial Africa. Cambridge: Cambridge University Press.

Holm, John. 1988. Pidgins and creoles. Volume 1: Theory and stnucture. Cambridge: Cambridge University Press.

Houis, Maurice. 1981. Anthropologie linguistique de l'Afrique noire. Paris: Presses Universitaires de France.

Hulstaert, G. 1952. Dictionnaire Franţais-Lomongo. Tervuren: Musée royal du Congo Belge.

- G. 1957. Dictionnaire Lomongo-Français. Tervuren: Musée royal du Congo Belge. . 1989. L'origine du Lingala. Afrikanistische Arbeitspapiere 17:81-114.

Johnston, Harry. 1983. A visit to Mr. Stanley's stations on the river Congo. Proceedings of the Royal Geographical Society, pp. 569-81.

- 1884. The river Congo from its mouth to Bolobio with a general description of the natural history and anthropology of its westem basin. 3rd edition. London: Sampson Low, Marston, Searle, and Rivington.

- 1908. George Grenfell and the Congo: $A$ history and description of the Congo Independent State and adjoining districts of Congoland ... 2 vols. London: Paternoster Row.

Knappert, Jan. 1979, Origin and development of Lingala. In Readings in creole studies, ed. Ian F. Hancock, pp. 153-64. Ghent: E. Story-Scientia.

Lekens, Benjamin. 1958. Ngbandi idioticon. Vol. 2: Ngbandi en Frans-Nederlands. (Annales du Musée royal du Congo Belge. Sciences de l'Homme. Linguistique, 3.) Tervuren: Musée royal de Congo Belge.

Lemaire, Charles F. 1894. Congo et Belgique: A propos de l'exposition d'Anvers. Bruxelles: Imprimerie Scientifique Charles Bulens.

- 1897. Vocabulaire pratique: Français, Anglais, Zanzibarite (Swahili), Fiote, KibangiIrébou, Mongo, Bangala. Bruxelles: Imprimerie Scientifique Ch[arles] Bulens.

Mahieu, Alfred. 1924. Numismatique du Congo, 1485-1924. Bruxelles: Imprimerie Médicale et Scientifique.

Maistre, Casimir. 1895. A travers l'Afrique Centrale du Congo au Niger, 1892-1893. Paris: Hachette et Cie. 
Mariaule, Albert. 1952. Nganga-Bouka, médecin-sorcier: Le père Cambier (1865-1943). (Collection Lavigerie, 43.) Namur: Grands Lacs.

Medley, E. 1892. Africa. In Centenary of the Baptist Missionary Society 1792-1892, ed. J.B. Myers, pp. 151-83. London: The Baptist Missionary Society.

The Missionary Herald. London: The Baptist Missionary Society.

Mufwene, Salikoko S. 1986. The universalist and substrate hypotheses complement one another. In Substrata versus universals in creole genesis, eds. Pieter Muysken and Norval Smith, pp. 129-62. Amsterdam: John Benjamins.

- 1988. Formal evidence of pidginization/creolization in Kituba. Joumal of African Languages and Linguistics 10:33-51.

Mumbanza mwa Bawele. 1980. Histoire des peuples riverains de l'entre-Zaïre-Ubangi: Evolution sociale et économique (ca. 1700-1930). These doctorale Lubumbashi, Universite Nationale du Zäre. 2 vols.

Ngalasso, Mwatha Musanji. 1981. Émergence et développement d'une langue véhiculaire: Le kikongo. In Caprille (ed.), pp. 43-72.

- 1986. État des langues et langues de l'État au Zaïre. Politique Africaine 23:7-27.

Nida, Eugene $A$. and Harold W. Fehderau. 1970. Indigenous pidgins and koinés. Intemational Joumal of American Linguistics 32:146-55.

Reinecke, John E., et al. 1975. $A$ bibliography of pidgin and creole languages. Honolulu: University of Hawaii Press.

Rhodes, Richard. 1982. Algonquian trade languages. In Papers of the thireenth Algonquian conference, ed. Willian Cowan, pp. 1-10. Ottawa: Carleton University.

Romaine, Suzanne. 1988. Pidgin and creole languages. London and New York: Longman.

Samarin, W.J. 1982a. Colonization and pidginization on the Ubangi River. Joumal of African Languages and Linguistics 4:1-42.

- 1982b. Goals, roles, and language skills in colonizing central equatorial Africa. Anthropological Linguistics 24:410-22.

- 1984. The linguistic world of field colonialism. Language in Society 13:435-53.

- 1984/1985. Communication by Ubangian water and word. Sprache und Geschichte in Afrika 6:309-73.

- 1985a. The State's Bakongo burden bearers. In The workers of African trade, eds. Catherine Coquery-Vidrovitch and Paul E. Lovejoy, pp. 269-92. Beverly Hills: Sage Publications.

- 1985b. Plurigenesis in pidginization. Joumal of Historical Linguistics and Philology 2(1/2):100-19.

-1986a. Chinook Jargon and pidgin historiography. Canadian Journal of Anthropology 5:23-34.

- 1986b. Protestant missions and the history of Lingala. Joumal of Religion in Africa $16(2): 138-63$.

_ 1986c. The source of Sango's 'be'. Joumal of Pidgin and Creole Languages 1:205-23.

. 1987. Lingua franca. In Sociolinguistics: An intemational handbook of the science of language and society, eds. U. Ammon, N. Dittmar, and K.J. Mattheier, pp. 371-74. Berlin, New York: Walter de Gruyter and Co.

-1989a. The black man's burden: African colonial labour on the Congo and Ubangi rivers 1880-1900. Boulder, Colorado: Westview Press.

__ 1989b. 'Official language': The case of Lingala. In Status and function of languages and language varieties, ed. Ulrich Ammon, pp. 386-98. Berlin: Mouton de Gruyter.

- 1989c. The colonial heritage of the Central African Republic: A linguistic perspective. Intemational Joumal of Africant Historical Studies 22(4):1-14.

—_. Forthcoming. La politique indigène dans l'histoire de Bangui. Revue Française d'Histoire d'Outre-Mer.

Thomason, Sarah Grey, and Terrence Kaufman. 1988. Language contoct, creolization, and genetic linguistics. Berkeley and Los Angeles: University of California Press. 
Thonner, Franz. 1899. Dans la grande forêt de l'Afrique centrale: Mon voyage au Congo et d la Mongala en 1896. Bruxelles: Societé belge de Librairie.

Tolmacheva, Marina. 1986. Toward a definition of the term Zanji. Azania 21:105-13.

Torday, E. 1905. Notes on the natives of the Kwilu, Congo Free State. Man 5(75);135-38.

Tuckey, J.K 1818. Narrative of an expedition to explore the River Zaire, usually called the Congo, in South Africa in 1816. London: John Murray.

van Everbroeck, R.F. 1956. Lingala woordenboek Lingala-Nederlands, Nederlands-Lingala. Brussels: Scheul Edities.

Vansina, Jan. 1973. The Tio kingdom of the Middle Congo 1880-1892. London: Oxford University Press.

- 1984. Western Bantu expansion. Journal of African History 25:129-45.

Vincent, Frank. 1895. Actual Africa, or, the coming continent: $A$ tour of inspection. New York: D. Appleton and Co.

Weeks, John H. 1913. Among Congo cannibals. London: Seeley, Service, and Co.

Whitehead, John. 1899. Grammar and dictionary of the Bobangi language. London: Baptist Missionary Society and Kegan Paul, Trench, Trübner and Co., and Ridgewood, New York: The Gregg Press (reprint, 1964).

- Language. Conference of Congo missionaries (Congo Protestant Council). Report of the second conference of missionaries of the Protestant societies working in Congoland, pp. 48-52. Bolobo.

Wtterwulghe [sic], Georges-François. 1903. Vocabulaire d l'usage des fonctionnaires se rendant dans les territoires du district de l'Uele et de l'enclave Redjaf-Lado. État Indépendant du Congo.

Dept. of Anthropology

University of Toronto 